\title{
Urban Language Variation in the North Region - Valunorte
}

\author{
Socorro Cardoso* \\ University of the State of Pará (Uepa), Brazil
}

Submission: July 10, 2018; Published: July 25, 2019

*Corresponding author: Socorro Cardoso, University of the State of Pará (Uepa), Belém, Pará, Brazil

\section{Opinion}

The importance of a faulted language for a scientific study of language resides not in being a linguistic modality, but rather in the variation and changes that incessantly transform language. This is because the main feature gives linings and heterogeneity. North region, in addition to the indispensable systematic and general description of Brazilian linguistic reality, is necessary, above all, to the diffusion of a teaching If a country's pluricultural nature is adequate, it will require, more or less, the collective effort to concretize more broadly-based studies that slightly increase the global understanding of two linguistic factors, or differences, to a variety of normative variations. These, yes, can be described, explained, analyzed and applied. As it will be to see human life, I insist, this study, not a set of assumptions that I see or hold an actor / author linked to a reality that I construed as a member of a community at the same time and built my own hair.

Studies on culture unfold this thought in a quite appropriate way to say that man and an animal suspense in is of meaning that even wove, thus understand culture as seunda one of these webs, and, its analysis, therefore, as being not an Experimental science in search of laws, but an interpretative science in search of meanings. We can expand this idea to verify that the social phenomena that integrate these, such as culture, language, and interaction, are imbricated and, at present, seen by some scholars, the research objects of the same research, favoring the development of multidisciplinary and interpretative studies. It is not so great that we reconnect that to the nature of the question is a choice of a determined academic position more subjective and without pre-conceived models of data to analyze certain questions concerning the interlocution and the language. In this case, we assume that the search is without a political act, in this case, a reaction has a process of linguistic domination, that occurred together with occupation territorial. These reflections, based on more recent linguistic research, leads, each time more, researchers to inquire about or observe and disagree in this diversity, as well as its procedures and purposes.
It is then verified that that or sense of these denominations or as in the field of geography, gives anthropology, gives sociology, gives psychology and gives education, especially to societies of literate culture, to understand their own denominator mentality, not only as an isolated element, but as a project of their social group. The University of Amazonia (UNAMA), or the Linguistic Variation of the North Region - VALINORTE at the State University of Pará (UEPA), who's objective and to install a computerized Data Bank based on the documentation of the resident subjects of the Islands in the urban centers of this region of Brazil. These points correspond to linguistically and geographically representative areas of the state of Pará. The purpose of these proves to elaborate a Bank of Dice - corpus balanced and representative of Portuguese of Brazil used in Pará. By balanced, understood-is composed of texts of situations of oral use. As a representative, it is understood as composting of representative texts of several different types of situations of use of oral language. A related objective is the participation of oral language genres, with more and more specific groups, raising, among other criteria, formality of situation, intimidation and hierarchy, two participants and the particularities of the situation.

It also intends to label the texts, so that they can be used for linguistic research. Or general objective and to install a computerized linguistic data bank, based on the documentation of resident subjects in linguistically representative and geographically positioned rural and urban areas. The specific objectives are to systematize the given function of higher frequency, according to the phonetic-phonological, morpho synthetic and semantic aspects; document as ocers to feed or Bank of Craps; constitute or Bank of Dice; discrete the contexts of uses and analyze quant qualitatively or corpus. Finally, this project intends to help develop a significant corpus of Portuguese oral language in Brazil, especially in the state of Pará. Thus, wait-set up the Dice Bank, which allows any interested to 
access, for studies and research, linguistic uses real, real, in real communication situations. The VALUNORTE Project does not intend to check an ideal of linguistic use, but to register or to a greater number of possible the occurrences and who are the subjects that use it.

\section{Your next submission with Juniper Publishers} will reach you the below assets

- Quality Editorial service

- Swift Peer Review

- Reprints availability

- E-prints Service

- Manuscript Podcast for convenient understanding

- Global attainment for your research

- Manuscript accessibility in different formats

( Pdf, E-pub, Full Text, Audio)

- Unceasing customer service

Track the below URL for one-step submission https://juniperpublishers.com/online-submission.php 